\title{
Inventory of Physical Activity Objectives - a new method of measuring motives for physical activity and sport
}

\section{BACKGROUND}

As a conscious activity of an individual, physical activity (PA) constitutes an element of the free-time dimension. The type of goal allows us to distinguish between sport and PA: sport performance vs. psychophysical health hence the idea to develop a tool for measurement of the motivational function of an objective in physical activity and sport.

\section{PARTICIPANTS AND PROCEDURE}

The normalisation sample consisted of 2141 individuals: 1163 women aged $16-64(M=23.90, S D=8.30)$ and 978 men aged $16-66(M=24.50, S D=9.40)$. In the process of validation, a factor analysis, and subsequently validity and reliability analysis of the tool, and normalisation of scales were performed.

\section{RESULTS}

Based on the factor analysis and the degree to which each of the given items conformed to the theory of the motivational function of an objective, the following scales were distinguished: 1) motivational value (the extent to which the objective influences the actions undertaken by an individual), 2) time management (the level of focus on plan- ning, arranging and organizing time for $\mathrm{PA})$, 3) persistence in action (efficiency and persistence of action, and the ability to deal with adversities), and 4) motivational conflict (the level of conflict: PA objectives vs. other objectives). The Cronbach's $\alpha$ reliability coefficient for this version reached .78. The Inventory of Physical Activity Objectives (IPAO) also included questions that allow one to control for variables such as the variety of forms, duration, and frequency of PA, and socio-demographic variables.

\section{CONCLUSIONS}

The IPAO, as a new method for measuring motives for physical activity and sport, is characterized by good psychometric properties. The IPAO can serve both scientific research and as a useful tool for personal trainers, helping diagnose the motives for engaging in PA and sports. With knowledge about the purposefulness of actions, it is possible to support and shape additional motivation experienced by an individual, by setting new, realistic objectives.

\section{KEY WORDS}

motivation; sport psychology; tool validation; exercises; pro-healthy behaviour

Organizations - 1: Department of Health Psychology, Gdansk University of Physical Education and Sport, Gdansk,

Poland · 2: Institute of Psychology, John Paul II Catholic University of Lublin, Lublin, Poland

Authors' Contribution - A: Study design - B: Data collection - C: Statistical analysis - D: Data interpretation .

E: Manuscript preparation · F: Literature search · G: Funds collection

CORResPonding AUthor - Prof. Mariusz Lipowski, Department of Health Psychology, Gdansk University of Physical

Education and Sport, 1 Kazimierza Górskiego Str., 80-336 Gdansk, Poland, e-mail: mariusz.lipowski@awfis.gda.pl

TO CITE THIS ARTICLE - Lipowski, M., \& Zaleski, Z. (2015). Inventory of Physical Activity Objectives - a new method

of measuring motives for physical activity and sport. Health Psychology Report, 3(1), 47-58. DOI: 10.5114/hpr.2015.49462

RECEIVED 11.01.2015 · REVIEWED 19.02.2015 · ACCEPTED 20.02.2015 • PUBLISHED 27.02.2015 
Nothing occurs at random, but everything for a reason and by necessity Leucippus (c. 480 B.C. - c. 420 B.C.)

\section{BACKGROUND}

Physical activity is defined as any bodily movement produced by skeletal muscles, and which requires energy expenditure (WHO, online). "Physical inactivity has been identified as the fourth leading risk factor for global mortality causing an estimated 3.20 million deaths globally. Regular, moderate intensity physical activity - such as walking, cycling, or participating in sports - has significant benefits for health. For instance, it can reduce the risk of cardiovascular diseases, diabetes, colon and breast cancer, and depression. Moreover adequate levels of physical activity will decrease the risk of a hip or vertebral fracture and help control weight" (WHO, online). Physicians recommend any form of physical activity (e.g. gardening) as conducive to health; however, this paper focuses on a particular type of physical activity. Physical activity undoubtedly is a goal-oriented behaviour, and it is inextricably linked to an objective. The type of goal allows us to distinguish between sport and physical activity (PA): sport performance vs. psychophysical health. Health-oriented physical activity increasingly attracts the interest of researchers, for the results suggest that PA has a beneficial influence not only on physical health, but also on mental health, e.g., in the case of people suffering from depression (Mata et al., 2012), anxiety disorders (Meng \& D'Arcy, 2013), eating disorders (Joseph, Alonso-Alonso, Bond, Pascual-Leone, \& Blackburn, 2011; Lipowski, Buliński, \& Krawczyński, 2009) as well as in treatment of alcohol-dependent individuals (Lipowski, Szulc, \& Buliński, 2015), or drug addicts (Lynch, Peterson, Sanchez, Abel, \& Smith, 2013). Systematic engagement in physical activity is recommended not only to children (Gubbels, Van Kann, de Vries, Thijs, \& Kremers, 2014), adolescents (Biddle \& Asare, 2011), adults, and elderly people (Middelweerd, Mollee, van der Wal, Brug, \& te Velde, 2014), but also to pregnant women (Guszkowska \& Langwald, 2014).

As a conscious activity of an individual, physical activity constitutes an element of the free-time dimension. As such, it is also a sequence of activities focused on fulfilment of tasks of varied time-frame, both long-term and short-term. The characteristics of the objective can be predicted from the action dimension (percent of accounted variance); however, this predictability showed a decrease corresponding to the time ranges. Specific goals and longer perspectives have been shown to increase persistence and satisfaction derived from pursuing short-term goals (Zaleski, 1987a). Planning to lose the extra fat tissue by a defined date is one example of this (Lipowski et al., 2009). The success of reaching the long-term goals depends on the planning and the achievement of short-term goals. An instructively created goal, that is, a vision of the end result associated with the plan, is an effective regulator, especially when there is a need to perform a series of actions. Hence, an individual engaging in physical activity would plan their engagement in activities with a will to find the most convenient time to exercise, the right outfit, the preferred means of transport, finding company, aiding the exercise with an appropriate diet, etc. The anticipation of the task's result itself grants a sense of fulfilment to the individual (Zaleski, 1991). The vision of the end result stimulates action, as if there were a direct transition from a cognitive state to motor acts. Knowledge about the outcome is a prerequisite for construction of the plan, in line with the philosophical rule: what emerges last in the course of action, must be known first.

When physical activity is the fulfilment of a goal, one can ask a question about its purposefulness, as well as about why, despite much evidence for its beneficial influence on psychophysical health, such small numbers of people engage in it. In Poland, 66\% (claim to!) engage in PA, and of those, $40 \%$ engage in PA systematically, and $26 \%$ sporadically (CBOS, 2013). Poles are most likely to engage in PA for their health (70\%) and for pleasure (61\%). Almost every second individual who engages in physical activity claims to work out for their wellbeing, in order to relieve stress, and/or to keep in good shape (47\%). Public Opinion Research Center (CBOS, 2013) also reports that the motivations behind engaging in different sport disciplines are diverse. Running, swimming, gymnastics and fitness classes, and cycling are mostly practised for health. Working out in a gym and body-building are practised about equally as often for health, as they are motivated by the desire to appear attractive - in order to look good, have a nice figure. On the other hand, pleasure is the main reason for dancing, hiking, soccer, winter sports, and volleyball.

The understanding of what an objective is can differ, depending on the assumed theory and its relevant terminology. In the current work, it is defined as a "future state that is cognitively represented, possible to achieve, has a value and regulatory power and is pursued by an individual through their actions" (Zaleski, 1991, p. 60). In the cognitive context, an objective refers to objects that exist in the world, their comparison, and encoding of a developed standard in memory. As such, it is an anticipated concept, a potential state. The possibility of achieving an objective makes it realistic, rather than remaining in the realm of fantasy. Because of that, for an individual, it has a subjective value and a specified meaning, whereby it has a functional role - it determines the actions. According to the classical works by Festinger (1957), setting an objective equates to the creation of a dis- 
crepancy, but the behaviour here is not necessarily aimed at the elimination of the dissonance and negative emotions, but rather at achieving the anticipated state of affairs, which has a value for the individual (Zaleski, 1991). However, goal-oriented behaviour (including PA) is motivated by the decision to act, rather than pressure forcing one to act. Accomplishing an objective does not necessarily mean achieving an equilibrium; it may be that the accomplishment of one goal becomes a starting point for further goals in a further perspective. Setting an objective, which could be a will to change oneself, can be a reason for behaviours directed at accomplishing the anticipated state (Zaleski, 1987b). Thus the stimulated action can be defined as freely undertaken activities that are goal-oriented and volitionally controlled, and which include planning, implementation of the plan and the assessment of its fulfilment (Mądrzycki, 2002).

The objectives that an individual sets can be looked at from various research perspectives, where one could devote each of those perspectives a separate elaboration. Concepts of personal projects (Little, 1983) or personal pursuits (Emmons, 1986) are most often discussed. Theoretical concepts are often accompanied by research tools, some of which are almost directly related to pro-health physical activity. The Personal Strivings Assessment Packet (PSAP) (Emmons, 1999) was developed based on the theory of personal pursuits by Emmons. In this method, the subject generates 15 personal pursuits, current concerns (Klinger, 1977) and life tasks (Cantor, Norem, Niedenthal, Langston, \& Brower, 1987). The PSAP was successfully used to study relationships between trait and motivation constructs and health-related outcomes (Bogg, Voss, Wood, \& Roberts, 2008). Many researchers refer to the Personal Projects Analysis (PPA) theory (Little \& Gee, 2007), in which objectives are assessed based on five factors: project meaning (satisfaction, self-identification, value congruency), structure (control, time, initiation, positive/ negative influence), community (visibility to others, importance assessment by others), efficacy (chances for accomplishment, progress, skills), and stress (challenge, stress, level of difficulty). The tool has been used to test whether perceptions of conflicting and facilitating personal goals, and actual daily time spent in their pursuit, predict accelerometer-assessed physical activity (Presseau, Tait, Johnston, Francis, \& Sniehotta, 2013). The importance of time for goaloriented behaviour was stressed by Feather and Bond (1994), who developed the Time Structure Questionnaire, which concerns such aspects of time use as organization, purpose, routine, planning, inertia, and daydreaming. Furthermore, it also encompasses four subscales: the Engagement Scale, Direction Scale, Structure Scale and Routine Scale. Another popular framework is the $2 \times 2$ Achievement Goal Framework (Elliot \& McGregor, 2001; Wojdyło \& Retowski,
2012), which makes an assessment of the tendency to set performance-approach vs. performance-avoidance goals, and mastery-approach vs. mastery-avoidance goals. This framework is widely used in the psychology of physical activity (Van Yperen, Blaga, \& Postmes, 2014). The Goal Attainment Scale (Kiresuk \& Sherman, 1968; Kiresuk, Smith, \& Cardillo, 1994; McDougal \& King, 2007), which assesses the level of accomplishment of an objective on a scale from -2 to +2 , finds a significant use in therapeutic practice and thus also health psychology. The Theory of Planned Behavior (TPB) also led to the development of a research method: the TPB Questionnaire (Ajzen, 1991, 2006; Ajzen \& Manstead, 2007), which distinguishes between four TACT factors (target, action, context, and time). The use of the TPB theory and the correlations between goals in the context of physical activity were discussed by Presseau, Sniehotta, Francis, and Gebhardt (2010), who reached the conclusion that the congruency of objectives is a good predictor of increasing physical activity, even above the planned levels. Research on physical activity using the TPB Questionnaire was recently conducted by Hobbs, Dixon, Johnston and Howie (2013) and Plotnikoff, Lubans, Costigan and McCargar (2013).

Riediger and Freund (2004) suggested an interesting framework referring to the correlations between different objectives set by an individual, in particular, their conflict and facilitation. The questionnaire based on this theory - the Intergoal Relations Questionnaire (IRQ) - measures the interference between goals relating to the devoted time, energy, financial expenditure, and incompatible strategies of accomplishing objectives. It is worth noting the use of IRQ to define goals that provoke people of various ages to engage in PA (Riediger \& Freund, 2004). The theory of the grit personality feature, referring to endurance and passion in pursuing long-term goals, is an important concept (Duckworth, Peterson, Matthews, \& Kelly, 2007). This theory is also informed by the research on the objectives for physical activity, suggesting that character can be a significant predictor of PA (Reed, 2014).

Scales based on Self-Determination Theory (Deci \& Ryan, 1985) are also used in order to assess the motives for PA. These include: the Sport Motivation Scale (Pelletier et al., 1995), the Exercise Motivation Scale (Li, 1999), the Exercise Motivation Inventory (Markland \& Hardy, 1993) as well as new versions, such as the Motivation for Physical Activity Measure (Frederick \& Ryan, 1993; Ryan, Frederick, Lepes, Rubio, \& Sheldon, 1997). The Recreational Exercise Motivation Measure (Rogers, 2000) is also popular, and it is mostly used in studying pro-health PA (Roubal, Jovaag, Park, \& Gennuso, 2015). However, most of the methods investigate just the motivation for engaging in sports or PA, not the motivational value, that is the impact of the assumed objective of this engagement
IPAO a method of measuring motives for physical activity and sport 
- hence the idea of creating a tool to study sport or $\mathrm{PA}$ in the context of goal-oriented actions.

\section{THE PROCESS OF DEVELOPING INVENTORY OF PHYSICAL ACTIVITY OBJECTIVES}

The idea to develop a new tool for the measurement of motivational function of an objective first arose in 2008. Previous research (Lipowski, 2006) that involved 1300 female members of fitness clubs revealed a great variety of objectives pursued. At that time, KCEL II by Zaleski (1987b) was used for studying the motivations. In the pilot study $(N=150)$, women engaging in PA completed an open-ended sentence: My objective associated with physical recreation is... The initial analyses of data revealed that some of the women defined objectives that could only be indirectly correlated with PA. These included: buying a new outfit, going on holiday, joining a new fitness $c l u b$, etc. There were some that could seem difficult to associate with PA such as: job change, having a second child, getting married. This provoked a rephrasing of the original statement to: My goal for engaging in physical activity is... thereby forcing the participant to provide an answer that is directly related to PA. Concrete objectives are stronger motives, and lead to increased fulfilment when compared to those generally (imprecisely) formulated, or those encapsulated in the phrase 'to try one's best' (Zaleski, 1987b). Concreteness refers to a clearly defined intention, e.g., the amount of kilograms one wants to lose in the case of weight loss being an objective. The level of precision is an important element of the motivational function of an objective (Zaleski, 1991).

In order to precisely define the objective of PA, after the pilot study, the objectives were arranged into 7 primary groups (Lipowski, 2006):

1. Improving the physique - probably the most common objective declared by women attending fitness clubs. Such objectives are related to the following answers from the pilot study: to improve the looks, to lose three kilograms, to have a better body, to get rid of excess fat tissue, to attain a nice physique, to sculpt the body, etc.

2. Maintaining the physique - stating a will to maintain the appearance based on the phrases: to maintain the current physique, to always have a beautiful physique, to avoid weight gain, to maintain the current appearance, to maintain a stable weight, to keep muscle tone, to avoid the yo-yo effect, to keep a firm body, etc.

3. Improvement of fitness - terms in the pilot study included: to improve physical functioning, improve the physical condition, strengthen the calves, thighs, buttocks, etc.

4. Staying fit - terms such as: to stay fit, to keep the current fitness levels, to stay in shape, to maintain physical fitness, etc.
5. Health - this category of objective was derived from the following phrases: to feel healthy, to attain better health, to increase the body's immunity, to get sick less frequently, to be healthy, etc.

6. Wellbeing - based on answers such as: to feel good, to improve the mood, to feel better, to relax, to limber up, to rest, etc.

7. Routine - this category of objective was inspired by statements such as: to routinely attend classes, to participate in classes, to commit to going to aerobics classes, to run regularly, to keep moving, etc. This last goal of women's engagement in physical recreation may raise objections - is it a real motive for action? However, a high frequency of occurrence of the above statements seems to justify treating 'routine' as one of the motives for activities in the field of physical recreation.

Despite the forced choice, and repeated requests to include a specific statement, as many as $16.50 \%$ of responding women did not define the main objective of their engagement in PA. The reasons for that should not be blamed on a lack of motives for engaging in PA, but rather should be sought in the lack of conscious perception of causality of one's own actions. One of the respondents, when asked: Why did you not choose any objective of recreation?, answered: But everybody knows why one works out!, another: I don't know myself what the most important [objective] is for me. Because of the need to further specify the objectives of PA, they were analysed once more - this time including a new pilot study conducted with a group of men $(N=180)$ engaging in different forms of PA, who also completed the statement: $M y$ goal for engaging in physical activity is... Based on this and the earlier pilot study, 12 goals were eventually included in the Inventory of Physical Activity Objectives (IPAO) ${ }^{1}$ :

1. Health (right levels of: blood pressure, cholesterol, body mass, etc.),

2. Physical fitness, being 'in shape',

3. Company of other people,

4. Fit, shapely body (beauty, sculpted and firm body),

5. Wellbeing,

6. Being physically active and fit according to fashion,

7. Boosting confidence, gaining appreciation from others,

8. Pleasure from physical activity,

9. Escape from everyday life,

10. Managing stress,

11. Fulfilling the need for activity,

12. Promoting PA by setting a behaviour example.

The above goals relate to many areas of an individual's life and needs: physical health, subjective well-being, and even social relations. A blank space is left for the participants to fill in the $13^{\text {th }}$ objective, in case there is an uncommon one. The 12 objectives are accompanied by a Likert scale (1-5), and the re- 
spondent is requested to assess the importance of the listed objectives, where 1 stands for completely unimportant and 5 for very important. In addition to measuring the attitude of the subjects towards particular goals, the individual scores on the Likert scales are summed up. The final score indicates the importance of heterogeneity of the objectives one sets.

In the next part of the questionnaire, the subject responds to 18 items, selecting (also on a Likert scale) to what extent he or she agrees with a given statement, where 1 means 'I do not agree at all' and 5 means 'I fully agree'. This part was based on the KCEL II test by Zaleski (1987b). In KCEL II, 22 items are classified in accordance with six scales: the dimensions of an objective (Importance, Expectations, and Conflict) and the dimensions of a goal-oriented activity (Exercise, Endurance, Satisfaction). Importance is understood as a rank that a given objective holds in the hierarchy of all personal goals; expectations refers to the probability of accomplishing the given goal as perceived by the individual; conflict defines to which extent a given goal competes with other goals set by the individual. In the case of the dimensions of goal-oriented actions, exercise refers to the total energy devoted to accomplishing the goal; endurance describes the tendency to repeatedly return to a given activity; satisfaction refers to the positive emotions associated with the fulfilment of the objective. The normalisation sample consisted of 2141 individuals: 1163 women aged 16-64 $(M=23.90, S D=8.30)$ and 978 men aged $16-66(M=24.50, S D=9.40)$. For this part of the questionnaire, a factor analysis using the Principal Components method was performed, with the Varimax method for axis rotation. This method allowed for the identification of four factors with an eigenvalue greater than 1 , and together they explain over $51 \%$ of the total variance. Structure analysis of these sub-scales suggests that their psychometric properties are at satisfactory levels (Table 1).

Scree plot and factor loadings (Figure 1, Table 2) also suggest that practically only four factors contribute a significant part of variance to the analysed phenomenon. One can therefore infer that those four factors are significant for the description of properties of the IPAO questionnaire. It is important to stress that KCEL II was developed for life objec- tives, while IPAO was developed for specific objectives, associated with physical activity - which may be the reason for inclusion of different items in the scales. Cronbach's $\alpha$ reliability analysis was used in order to verify the internal consistency of the questionnaire: the reliability of the tool was assessed as $\alpha=.83$, which is a satisfactory level of reliability. The mean correlation between the items was moderately satisfactory and equalled .18. Item no. 15 contributed equally to loading of factors I and II; therefore it was removed from the questionnaire. In order to obtain the highest possible Cronbach's $\alpha$ reliability coefficient, and so that the four newly obtained sub-scales would best fit the theoretical propositions, three additional items were removed $(2,4,12)$. After gathering the opinions of assessors (seven university lecturers: five psychologists and two sport theorists), the scales were re-named. Based on the factor analysis and the degree to which each of the given items conformed to the theory of the motivational function of an objective, the following scales were distinguished: 1) motivational value (the extent to which the objective influences the actions undertaken by an individual), 2) time management (the level of focus on planning, arranging and organizing time for PA), 3) persistence in action (efficiency and persistence of action, and the ability to deal with adversities), and

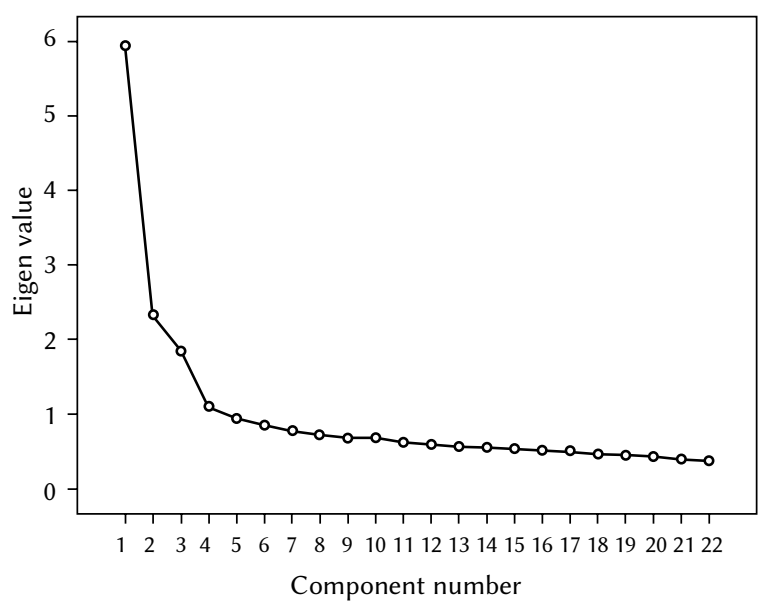

Figure 1. Scree plot - factor analysis of the IPAO.
IPAO a method of measuring motives for physical activity and sport

Table 1

Summary of factor analysis for extracting sub-scales in IPAO

\begin{tabular}{ccccc}
\hline \multirow{2}{*}{ Factor } & \multicolumn{3}{c}{ Sums of squares after the extraction } & \multirow{2}{*}{$\begin{array}{c}\text { Sum of squares after } \\
\text { rotation }\end{array}$} \\
\cline { 2 - 4 } & Total & \% of explained variance & Cumulated \% & 4.08 \\
2 & 5.94 & 26.99 & 26.99 & 3.22 \\
3 & 2.34 & 10.63 & 37.62 & 2.14 \\
4 & 1.85 & 8.41 & 46.03 & 1.79 \\
\hline
\end{tabular}


Mariusz Lipowski, Zbigniew Zaleski
4) motivational conflict (the level of conflict: PA objectives vs. other objectives). The Cronbach's $\alpha$ reliability coefficient for this version reached .78 (Table 3).

Reliability analysis for the four scales was performed in order to check the internal consistency of each factor. The results are satisfactory, and the mean correlations between the items are relatively high, reflecting the internal consistency of the individual scales (Tables 4, 5).

Apart from the listed objectives and their motivational function, a respondent has to fill in an extensive demographic questionnaire, referring most of all to their engagement in PA and sport. First they need to answer questions about gender, age, body mass, and height. The two latter parameters are used to calculate the body mass index (BMI), which is the body mass-height ratio. The BMI is the most popular and widely known mass-height index, allowing for an approximate evaluation of the amount of fatty tissue in the organism. For adults, BMI below 18.50 suggests

Table 2

Factor loadings of IPAO items after Varimax rotation

\begin{tabular}{|c|c|c|c|c|}
\hline \multirow{2}{*}{$\begin{array}{l}\text { Test } \\
\text { item }\end{array}$} & \multicolumn{4}{|c|}{ Factor } \\
\hline & I & II & III & IV \\
\hline 7 & 0.72 & 0.07 & 0.07 & 0.16 \\
\hline 19 & 0.71 & 0.23 & 0.09 & 0.00 \\
\hline 5 & 0.69 & 0.21 & 0.09 & 0.04 \\
\hline 17 & 0.67 & 0.13 & -0.01 & -0.13 \\
\hline 9 & 0.61 & 0.38 & 0.01 & 0.02 \\
\hline 11 & 0.59 & 0.33 & 0.07 & 0.02 \\
\hline 1 & 0.57 & 0.18 & 0.23 & 0.25 \\
\hline 6 & 0.54 & 0.21 & -0.31 & -0.16 \\
\hline 15 & 0.48 & 0.47 & 0.19 & 0.07 \\
\hline 21 & 0.10 & 0.73 & -0.11 & -0.05 \\
\hline 22 & 0.14 & 0.69 & 0.11 & 0.00 \\
\hline 12 & 0.15 & 0.61 & -0.28 & 0.03 \\
\hline 10 & 0.28 & 0.56 & -0.21 & -0.10 \\
\hline 3 & 0.38 & 0.56 & -0.11 & -0.11 \\
\hline 13 & 0.29 & 0.50 & 0.09 & 0.30 \\
\hline 2 & -0.26 & -0.49 & 0.13 & 0.18 \\
\hline 18 & 0.19 & -0.07 & 0.75 & 0.00 \\
\hline 20 & 0.05 & -0.04 & 0.70 & -0.08 \\
\hline 16 & 0.22 & 0.02 & 0.58 & -0.36 \\
\hline 4 & 0.24 & 0.20 & -0.57 & -0.11 \\
\hline 14 & 0.04 & -0.03 & -0.02 & 0.85 \\
\hline 8 & 0.08 & -0.10 & -0.13 & 0.79 \\
\hline
\end{tabular}

that a person is underweight; $18.50-24.90$ is regarded as the normal weight range; above 25.00 suggests that a person is overweight; and over 30 indicates obesity. Despite the great popularity of the index, one needs to note that it does not take into account the composition of our bodies - the ratio between muscle tissue and fat tissue. This is why it is unreliable in the cases of athletes, children, and pregnant women.

Further questions deal with residence and education. Subsequent to these, questions deal with training for competitive sports and athletic past - the respondent is asked to provide the discipline, the period of training, and the competitive level. One can be confident that both current training for competitive sports and such training in the past are important for setting objectives, and most of all for understanding those objectives.

The following part refers to engagement in classes (in fitness and sport clubs) and solitary training - the respondent is asked about the monthly frequency. Then the respondent has to declare which forms of PA they engage in and how many hours they devote to this activity. There is a choice of 13 forms of activity (gym, swimming, running, team sports, fitness,

Table 3

Reliability of IPAO

\begin{tabular}{|c|c|c|}
\hline \multicolumn{3}{|c|}{$\alpha=.78$, mean correlation between items: .17} \\
\hline $\begin{array}{l}\text { Test } \\
\text { item }\end{array}$ & $\begin{array}{l}\text { Test-item } \\
\text { correlation }\end{array}$ & $\begin{array}{l}\text { Reliability after } \\
\text { removing the item }\end{array}$ \\
\hline 1 & .41 & .76 \\
\hline 3 & .51 & .76 \\
\hline 5 & .50 & .76 \\
\hline 6 & .45 & .76 \\
\hline 7 & .47 & .76 \\
\hline 8 & .12 & .78 \\
\hline 9 & .57 & .75 \\
\hline 10 & .48 & .76 \\
\hline 11 & .51 & .76 \\
\hline 13 & .44 & .76 \\
\hline 14 & .13 & .78 \\
\hline 16 & .01 & .79 \\
\hline 17 & .46 & .76 \\
\hline 18 & .04 & .79 \\
\hline 19 & .51 & .76 \\
\hline 20 & .13 & .78 \\
\hline 21 & .44 & .76 \\
\hline 22 & .40 & .76 \\
\hline
\end{tabular}


Nordic walking, tennis/squash, dancing, rollerblading, martial arts, cycling, yoga, and gymnastics) and one blank spot - left to be filled in if a respondent engages in a different form of activity. This part of the questionnaire was repeatedly adjusted before it reached its final form. The pilot studies included open questions, whereas in the second stage they were grouped (e.g. cross-country running, treadmill, jogging were all grouped as running). Assessment of the frequency and intensity made for another difficulty - as e.g. body building is very different to swimming or team sports. In the pilot, each respondent had to provide the weekly number of hours devoted to a given form of activity. However, after summing up, it turned out that some of the subjects would devote even 400 (!) hours a month to such activities, which would mean 13 hours a day. Taking into account the fact that even professional athletes during intense training periods devote usually no more than 5 hours a day to training ( 2 training sessions), such extensive devotion of time seems impossible - and those numbers were declared by people who do not engage in competitive sports. Problematic questionnaires such as this were eliminated from further analyses, since they were not reliable. This question was later changed to request a monthly number of hours and a choice between systematic and sporadic engagement. This last choice was introduced since one could assume that regular engagement in sport or PA requires higher organisation, and hence planning of free time, than when something is done only from time to time. Apart from that, one could engage in a given activity regularly, but with the frequency of once or twice a month for two hours - in such a case, the answer to the question how many times a week? would be difficult. One should remember that the purpose of the IPAO questionnaire is not to measure the intensity of physical activity, but the motivational function of an objective.
Table 4

Reliability of sub-scales

\begin{tabular}{|c|c|c|c|}
\hline Test item & $\begin{array}{l}\text { Item-scale } \\
\text { correlation }\end{array}$ & $\begin{array}{l}\text { Reliability after } \\
\text { removing the item }\end{array}$ & \multirow{10}{*}{$\begin{array}{l}\text { IPAO - } \\
\text { a method } \\
\text { of measuring } \\
\text { motives for } \\
\text { physical } \\
\text { activity } \\
\text { and sport }\end{array}$} \\
\hline \multicolumn{3}{|c|}{$\begin{array}{c}\text { Motivational value } \\
\text { 83, mean between-item correlation: } .39\end{array}$} & \\
\hline 1 & .49 & .82 & \\
\hline 5 & .61 & .81 & \\
\hline 6 & .44 & .83 & \\
\hline 7 & .59 & .81 & \\
\hline 9 & .60 & .81 & \\
\hline 11 & .57 & .81 & \\
\hline 17 & .54 & .81 & \\
\hline 19 & .63 & .80 & \\
\hline
\end{tabular}

Time management

$\alpha=.71$, mean between-item correlation: .33

\begin{tabular}{ccc}
\hline 3 & .51 & .65 \\
10 & .48 & .66 \\
13 & .37 & .70 \\
21 & .52 & .64 \\
22 & .46 & .67 \\
\hline
\end{tabular}

Persistence in action

$\alpha=.64$, mean between-item correlation: .37

\begin{tabular}{ccc}
\hline 16 & .42 & .57 \\
18 & .46 & .51 \\
20 & .45 & .53 \\
\hline \multicolumn{3}{c}{ Motivational conflict } \\
$\alpha=.71$, mean between-item correlation: .55 \\
\hline 8 & .55 & - \\
14 & .55 & - \\
\hline
\end{tabular}

Table 5

Norms for sub-scales and for heterogeneity of objectives

\begin{tabular}{rccccc}
\hline Sten & $\begin{array}{c}\text { Motivational } \\
\text { value }\end{array}$ & $\begin{array}{c}\text { Time } \\
\text { management }\end{array}$ & $\begin{array}{c}\text { Persistence in } \\
\text { action }\end{array}$ & $\begin{array}{c}\text { Motivational } \\
\text { conflict }\end{array}$ & $\begin{array}{c}\text { Importance } \\
\text { of heterogeneity } \\
\text { of objectives }\end{array}$ \\
\hline 1 & $\leq 21$ & $\leq 11$ & $\leq 7$ & $\leq 2$ & $\leq 30$ \\
2 & $22-25$ & $12-14$ & 8 & 3 & $31-35$ \\
3 & $26-28$ & $15-16$ & $9-10$ & 4 & $36-38$ \\
4 & $29-31$ & $17-18$ & 11 & 5 & $39-42$ \\
5 & $32-34$ & $19-21$ & 12 & 6 & $43-46$ \\
6 & $35-37$ & $22-23$ & $13-14$ & 7 & $47-49$ \\
7 & $38-40$ & $24-25$ & 15 & 8 & $50-53$ \\
8 & $41-43$ & $26-27$ & 16 & 9 & $54-56$ \\
9 & $44-45$ & $28-30$ & $17-18$ & 10 & $57-60$ \\
10 & - & $31-35$ & $19-20$ & - & - \\
\hline
\end{tabular}


Mariusz Lipowski, Zbigniew Zaleski
Further questions deal with seasonal PA. The pilot included a free choice, and the respondent was asked to provide the number of hours a day and days a year. Again, such phrasing led to difficulties. Some of the respondents would multiply the number of days by weeks and again, as in the case of the weekly number of hours in the previous question, they ended up with unrealistic estimations that were beyond the adaptive abilities of a human body to physical exercise. The question was left in the questionnaire, but the respondents are now asked only to provide the number of weeks a year they engage in activities such as skiing/snowboarding/ice-skating, windsurfing/kitesurfing, or providing another activity (and specifying the number of weeks devoted to that activity).

The questionnaire also includes a question about the period of engagement in PA or sport - getting an answer to this question may give insight into the experience of the individual in the area of planning objectives. One can suppose that the longer the period of engagement, the more realistic the goals. The following part of the questionnaire tests the attitude of an individual towards PA in terms of social relations - the subject assesses to what extent a given behaviour applies to them (Likert scale: 1 - not at all, 5 - a lot). This part includes statements referring to the favourable atmosphere in one's family or workplace encouraging PA, the availability of prerequisites to engage in PA, or cheering at sport events.

The Inventory of Physical Activity Objectives has already been used to study both competitive sportsmen and individuals recreationally engaging in physical activity. It proved useful in the analyses of pro-health PA of managers and officers of merchant navies (Lipowski, Lipowska, Peplińska, \& Jeżewska, 2014), individuals on weight-loss regimes (Lipowski et al., 2009), and alcohol-dependent individuals (Lipowski et al., 2015). The tool has also been included in research projects exploring risky behaviours of adolescents and motives for engaging in extreme sports.

\section{CONCLUSIONS}

The Inventory of Physical Activity Objectives, as a new method for measuring motives for physical activity and sport, is characterized by good psychometric properties (validity and reliability). Four scales of goal-oriented behaviours associated with PA are distinguished in the test: 1 ) motivational value, 2) time management, 3) persistence in action, and 4) motivational conflict. There are also a lot of questions that allow one to control for variables such as the variety of forms, duration, and frequency of PA, and socio-demographic variables. The IPAO may be useful in research in the fields of psychology, health sciences and sport science. It can also be used by practitioners - e.g. personal trainers diagnosing the motives of engaging in PA and sport, physicians who promote pro-health $\mathrm{PA}$, as well as therapists who include PA in the therapeutic process. The IPAO therefore has a diagnostic, auxiliary and explanatory value. It can aid projects aimed at studying well-being, satisfaction with life (at any stage of life), time management, coping with stress in business environments, psychotherapy for individuals affected with mood or eating disorders, or broadly defined personal problems. With knowledge about the purposefulness of actions, it is possible to support and shape additional motivation experienced by an individual, by setting new, realistic objectives.

\section{ENDNOTE}

1 A Polish version of the Inventory of Physical Activity Objectives [Kwestionariusz Celów Aktywności Fizycz$n e j]$ is downloadable at www.pracowniatestow.pl.

\section{RefERENCES}

Ajzen, I. (1991). The theory of planned behavior. Organizational Behavior and Human Decision Processes, 50, 179-211. DOI: 10.1016/0749-5978(91)90020-T

Ajzen, I. (2006). Constructing a TPB Questionnaire: Conceptual and Methodological Considerations. http://www.people.umass.edu/aizen/pdf/tpb.measurement.pdf.

Ajzen, I., \& Manstead, A. S. R. (2007). Changing healthrelated behaviors: An approach based on the theory of planned behavior. In: K. van den Bos, M. Hewstone, J. de Wit, H. Schut, \& M. Stroebe (eds.), The scope of social psychology: Theory and applications (pp. 43-63). New York: Psychology Press.

Biddle, S. J., \& Asare, M. (2011). Physical activity and mental health in children and adolescents: a review of reviews. British Journal of Sports Medicine, 45, 886-895. DOI: 10.1136/bjsports-2011-090185

Bogg, T., Voss, M. W., Wood, D., \& Roberts, B. W. (2008). A hierarchical investigation of personality and behavior: Examining Neo-Socioanalytic models of health-related outcomes. Journal of Research in Personality, 42, 183-207. DOI: 10.1016/j.jrp. 2007.05.003

Cantor, N., Norem, J. K., Niedenthal, P. M., Langston, C. A., \& Brower, A. M. (1987). Life tasks, self-concept ideals, and cognitive strategies in a life transition. Journal Of Personality And Social Psychology, 53, 1178-1191. DOI: 10.1037/0022-3514.53.6.1178

Centrum Badania Opinii Społecznej (2013). Aktywność fizyczna Polaków [Physical activity of Poles]. Warszawa: CBOS.

Deci, E. L., \& Ryan, R. M. (1985). Intrinsic motivation and self-determinaton in human behaviour. New York: Plenum. 
Duckworth, A. L., Peterson, C., Matthews, M. D., \& Kelly, D. R. (2007). Grit: Perseverance and passion for long-term goals. Journal of Personality and Social Psychology, 92, 1087-1101. DOI: 10.1037/0022-3514.92.6.1087

Elliot, A. J., \& McGregor, H. A. (2001). A 2 × 2 Achievement Goal Framework. Journal Of Personality Social Psychology, 80, 501-519.

Emmons, R. A. (1986). Personal strivings: An approach to personality and subjective well-being. Journal of Personality and Social Psychology, 51, 1058.

Emmons, R. A. (1999). The psychology of ultimate concerns: Motivation and spirituality in personality. New York, NY, US: Guilford Press.

Feather, N., \& Bond, M. (1994). Structure and purpose in the use of time. In: Z. Zaleski (ed.), Psychology of future orientation (pp. 121-140). Lublin: TN KUL.

Festinger, L. (1957). A theory of cognitive dissonance. Evanston IL: Row, Peterson.

Frederick, C., \& Ryan, R. (1993). Differences in motivation for sport and exercise and their relations with participation and mental health. Journal of Sport Behavior, 16, 124-146.

Gubbels, J. S., Van Kann, D. H. H., de Vries, N. K., Thijs, C., \& Kremers, S. P. J. (2014). The next step in health behavior research: the need for ecological moderation analyses - an application to diet and physical activity at childcare. International Journal of Behavioral Nutrition \& Physical Activity, 11, 1-25. DOI: 10.1186/1479-5868-11-52.

Guszkowska, M., \& Langwald, M. (2014). Changes in satisfaction with body in pregnant women participating in physical exercise classes and childbirth classes. Health Psychology Report, 2, 152-161. DOI: 10.5114/hpr.2014.44424

Hobbs, N., Dixon, D., Johnston, M., \& Howie, K. (2013). Can the theory of planned behaviour predict the physical activity behaviour of individuals? Psychology \& Health, 28, 234-249. DOI: 10.1080/08870446.2012.716838

Joseph, R. J., Alonso-Alonso, M., Bond, D. S., Pascual-Leone, A., \& Blackburn, G. L. (2011). The neurocognitive connection between physical activity and eating behaviour. Obesity Reviews, 12, 800812. DOI: 10.1111/j.1467-789X.2011.00893.x

Kiresuk, T. J., Smith, A., \& Cardillo, J. E. (1994). Goal attainment scaling: Applications, theory and measurement. Hillsdale, NJ: Erlbaum.

Kiresuk, T., \& Sherman, R. (1968). Goal attainment scaling: A general method for evaluating comprehensive community mental health programs. Community Mental Health Journal, 4, 443-453.

Klinger, E. (1977). Meaning and void: Inner experience and the incentives in people's lives. Minneapolis: University of Minnesota Press.
Li, F. (1999). The exercise motivation scale: its multifaceted structure and construct validity. Journal of Applied Sport Psychology, 11, 97-115.

Lipowski, M. (2006). Rekreacja ruchowa kobiet jako zachowanie prozdrowotne-uwarunkowania a motywy uczestnictwa [Physical activity of women as pro-health behaviour - determinants and motives of participation]. Gdańsk: Wydawnictwo AWFiS.

Lipowski, M., Buliński, L., \& Krawczyński, M. (2009). Physical activities among other types of health-related behaviour in people losing weight. Medical Science Monitor, 15, CR423-428.

Lipowski, M., Lipowska, M., Peplińska, A., \& Jeżewska, M. (2014). Personality determinants of health behaviours of merchant navy officers. International Maritime Health, 65, 158-165. DOI: 10.5603/ IMH.2014.0030

Lipowski, M., Szulc, M., \& Buliński, L. (2015). Physical activity among other health-related behaviors in treatment of alcoholism. Journal of Sports Medicine and Physical Fitness (in press).

Little, B. R. (1983). Personal projects: A rationale and method for investigation. Environment and Behavior, 15, 273-309.

Little, B. R., \& Gee, T. L. (2007). The methodology of personal project analysis: Four modules and a funnel. In: B. R. Little, K. Salmela-Aro, \& S. D. Phillips (eds.), Personal project pursuit: Goals, action, and human flourishing (pp. 51-93). London: Lawrence Erlbaum.

Lynch, W. J., Peterson, A. B., Sanchez, V., Abel, J., \& Smith, M. A. (2013). Exercise as a novel treatment for drug addiction: A neurobiological and stage-dependent hypothesis. Neuroscience and Biobehavioral Reviews, 37, 1622-1644. DOI: 10.1016/j.neubiorev.2013.06.011

Mądrzycki, T. (2002). Osobowość jako system tworzący $i$ realizujacy plany [Personality as a system creating and implementing plans]. Gdańsk: Wydawnictwo Uniwersytetu Gdańskiego.

Markland, D., \& Hardy, L. (1993). The exercise motivations inventory: preliminary development and validity of a measure of individuals' reasons for participation in regular physical exercise. Personality and Individual Differences, 15, 289-296.

Mata, J., Thompson, R. J., Jaeggi, S. M., Buschkuehl, M., Jonides, J., \& Gotlib, I. H. (2012). Walk on the bright side: physical activity and affect in major depressive disorder. Journal of Abnormal Psychology, 121, 297-308. DOI: 10.1037/a0023533

McDougal, J., \& King, G. (2007). Goal Attaintment Scaling: Descriptions, Utility and Applications in Pediatric Therapy Services. Thames Valley Childrens Centre.

Meng, X., \& D’Arcy, C. (2013). The projected effect of increasing physical activity on reducing the prevalence of common mental disorders among Canadian men and women: a national popula-
IPAO a method of measuring motives for physical activity and sport 
Mariusz Lipowski, Zbigniew Zaleski tion-based community study. Preventive Medicine, 56, 59-63. DOI: 10.1016/j.ypmed.2012.11.014.

Middelweerd, A., Mollee, J., van der Wal, C., Brug, J., \& te Velde, S. (2014). Apps to promote physical activity among adults: A review and content analysis. International Journal of Behavioral Nutrition \& Physical Activity, 11, 1-15. DOI: 10.1186/s12966014-0097-9.

Pelletier, L. G., Tuson, K. M., Fortier, M. S., Vallerand, R. J., Briere, N. M., \& Blais, M. R. (1995). Toward a measure of intrisic motivation, extrinsic motivation, and motivation in sport- the sport motivation scale (SMS). Journal of Sport \& Exercise Psychology, 17, 35-53.

Plotnikoff, R. C., Lubans, D. R., Costigan, S. A., \& McCargar, L. (2013). A Test of the Theory of Planned Behavior to Predict Physical Activity in an Overweight/Obese Population Sample of Adolescents from Alberta, Canada. Health Education \& Behavior, 40, 415-425.

Presseau, J., Sniehotta, F. F., Francis, J. J., \& Gebhardt, W. A. (2010). With a little help from my goals: Integrating intergoal facilitation with the theory of planned behaviour to predict physical activity. British Journal of Health Psychology, 15, 905-919. DOI: 10.1348/135910710X494105

Presseau, J., Tait, R. I., Johnston, D. W., Francis, J. J., \& Sniehotta, F. F. (2013). Goal conflict and goal facilitation as predictors of daily accelerometer-assessed physical activity. Health Psychology, 32, 1179-1187. DOI: $10.1037 / \mathrm{a} 0029430$

Reed, J. (2014). A Survey of Grit and Exercise Behavior. Journal of Sport Behavior, 37, 390-406.

Riediger, M., \& Freund, A. M. (2004). Interference and facilitation among personal goals: Differential associations with subjective well-being and persistent goal pursuit. Personality and Social Psychology Bulletin, 30, 1511-1523. DOI: 10.1177/0146167204271184

Rogers, H. (2000). Development of a Recreational Exercise Motivation Questionnaire. Melbourne, Australia: Victoria University.

Roubal, A. M., Jovaag, A., Park, H., \& Gennuso, K. P. (2015). Development of a nationally representative built environment measure of access to exercise opportunities. Preventing Chronic Disease, 12, 140378. DOI: $10.5888 /$ pcd 12. 140378

Ryan, R., Frederick, C., Lepes, D., Rubio, N., \& Sheldon, K. (1997). Intrinsic motivation and exercise adherence. International Journal of Sport Psychology, 28, 235-254.

Van Yperen, N. W., Blaga, M., \& Postmes, T. (2014). A meta-analysis of self-reported achievement goals and nonself-report performance across three achievement domains (work, sports, and education). PLoS One, 9, 1-16. DOI: 10.1371/journal. pone.0093594
Wojdyło, K., \& Retowski, S. (2012). Kwestionariusz celów osiągnięć - analiza rzetelności i trafności teoretycznej narzędzia [Questionnaire of goals associated with achievements-analysis of reliability and theoretical validity of the tool]. Przeglad Psychologiczny, 55, 9-28.

World Health Organization (online). Physical activity. Retrieved from: http://www.who.int/topics/ physical_activity/en.

Zaleski, Z. (1987a). Behavioral effects of self-set goals for different time ranges. International Journal of Psychology, 22, 17-38. DOI: 10.1080/ 00207598708246765

Zaleski, Z. (1987b). Motywacyjna funkcja celów w dziatalności człowieka [Motivational function of goals in human activity]. Lublin: RW KUL.

Zaleski, Z. (1991). Psychologia zachowań celowych [Psychology of goal-directed behaviour]. Warszawa: PWN. 


\section{Appendix}

\section{Inventory of Physical Activity Objectives}

Lipowski \& Zaleski

In this questionnaire we will ask you about the objectives of your involvement in physical activity and sports.

The term physical activity $(\mathbf{P A})$ is used here to describe those activities that specifically require physical effort. Please be as honest as possible, because only genuine answers will be of scientific value to us!

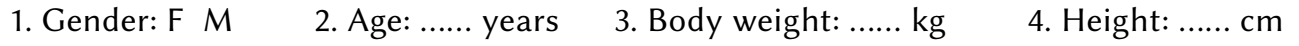

5. Residence: village $\square \quad$ small town (up to 20000 inhabitants) $\square$ medium town/city (20 000-100 000 inhabitants) $\square \quad$ big city (more than 100000 inhabitants) $\square$

6. Education: primary $\square \quad$ vocational $\square \quad$ secondary $\square \quad$ higher: BA/BSc $\square$ higher: MA/MSc $\square$

7. Do you currently practise any competitive sport? no yes - which one?

For how many years? ...... Assigned class ......

8. Have you ever taken part in competitive sports? no yes - which one?

For how many years? ...... Assigned class ......

9. Do you participate in classes (e.g. in a fitness club/gym)? no yes times a month

10. Do you engage in PA on your own? no yes ...... times a month

11. What types of PA are you involved in, and how many hours per month do you spend on them?

(check REG for "regularly" or OCC for "occasionally")

\begin{tabular}{|c|c|c|c|c|}
\hline body building & ..... hours & $\square$ REG $\square$ OCC & dancing & ..... hours $\square$ REG $\square$ OCC \\
\hline swimming & ..... hours & $\square$ REG $\square$ OCC & rollerblading & ..... hours $\square$ REG $\square$ OCC \\
\hline running & ..... hours & $\square$ REG $\square$ OCC & martial arts & ..... hours $\square$ REG $\square$ OCC \\
\hline team games & ..... hours & $\square$ REG $\square$ OCC & cycling & ..... hours $\square$ \\
\hline fitness & ..... hours & $\square$ REG $\square$ OCC & yoga & ..... hours \\
\hline nordic walking & ..... hours & $\square$ REG $\square$ OCC & gymnastics & ..... hours \\
\hline nnis/squash & ..... hours & $\square$ REG $\square$ OCC & other: & ..... hours \\
\hline
\end{tabular}

12. What types of seasonal PA do you engage in and with what intensity?

$\begin{array}{ll}\text { Skiing/snowboarding/ice skating } & \text { for ...... weeks during the season } \\ \text { windsurfing/kitesurfing } & \text { for ....... weeks during the season } \\ \text { other: ....................................... } & \text { for ....... weeks during the season }\end{array}$

13. For how long have you been regularly (without longer intervals) engaged in PA?

..... months ...... years

14. Assess to what extent the listed behaviours apply to you: not at all $\diamond \begin{array}{lllll} & 2 & 4 & 5\end{array} \Rightarrow$ very much

\begin{tabular}{|c|c|c|c|c|c|c|}
\hline 1 & $\begin{array}{l}\text { There is an encouraging (mobilizing) attitude towards sports among my family } \\
\text { (and friends). }\end{array}$ & & 2 & 3 & 4 & \\
\hline 2 & $\begin{array}{l}\text { There is an encouraging (mobilizing) attitude towards sports in my work } \\
\text { environment. }\end{array}$ & 1 & 2 & 3 & 4 & 5 \\
\hline 3 & $\begin{array}{l}\text { I have the prerequisites to engage in PA (the availability of fitness clubs } \\
\text { and/or natural surroundings). }\end{array}$ & 1 & 2 & 3 & 4 & 5 \\
\hline 4 & I am interested in TV/radio/web sportscasts (I watch/listen to them). & 1 & 2 & 3 & 4 & $J$ \\
\hline 5 & I participate in sports events (tournaments, matches, etc.) as a fan. & 1 & 2 & 3 & 4 & 5 \\
\hline
\end{tabular}


15. Please determine how important to you the following goals of engaging in physical activity are: not important at all $\diamond \begin{array}{lllllll}1 & 2 & 3 & 4 & 5 & \Rightarrow & \text { very important }\end{array}$

Mariusz Lipowski, Zbigniew Zaleski

\begin{tabular}{|c|c|c|c|c|c|c|}
\hline 1 & Health (right levels of: blood pressure, cholesterol, body mass, etc.) & 1 & 2 & 3 & 4 & 5 \\
\hline 2 & Physical fitness, being 'in shape' & 1 & 2 & 3 & 4 & 5 \\
\hline 3 & Company of other people & 1 & 2 & 3 & 4 & 5 \\
\hline 4 & Fit, shapely body (beauty, sculpted and firm body) & 1 & 2 & 3 & 4 & 5 \\
\hline 5 & Wellbeing & 1 & 2 & 3 & 4 & 5 \\
\hline 6 & Being physically active and fit according to fashion & 1 & 2 & 3 & 4 & 5 \\
\hline 7 & Boosting confidence, gaining appreciation from others & 1 & 2 & 3 & 4 & 5 \\
\hline 8 & Pleasure from physical activity & 1 & 2 & 3 & 4 & 5 \\
\hline 9 & Escape from everyday life & 1 & 2 & 3 & 4 & 5 \\
\hline 10 & Managing stress & 1 & 2 & 3 & 4 & 5 \\
\hline 11 & Fulfilling the need for activity & 1 & 2 & 3 & 4 & 5 \\
\hline 12 & Promoting PA by setting a behaviour example & 1 & 2 & 3 & 4 & 5 \\
\hline 13 & Other: & 1 & 2 & 3 & 4 & 5 \\
\hline
\end{tabular}

16. Bearing in mind your most important goal of physical activity from the list above, please decide how true in your case each of the following statements is. I am describing goal no ......

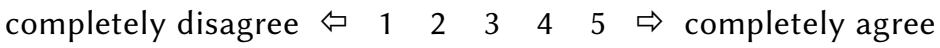

\begin{tabular}{|c|c|c|c|c|c|c|}
\hline 1 & I am deeply convinced that I will achieve this goal. & 1 & 2 & 3 & 4 & 5 \\
\hline 2 & I devote my entire free time to accomplishing this goal. & 1 & 2 & 3 & 4 & 5 \\
\hline 3 & I find it pleasurable to deal with matters associated with this goal. & 1 & 2 & 3 & 4 & 5 \\
\hline 4 & $\begin{array}{l}\text { If it turned out that for some reason this goal could not be achieved, I would } \\
\text { experience a great loss. }\end{array}$ & 1 & 2 & 3 & 4 & 5 \\
\hline 5 & I am certain that my efforts will be fruitful in accomplishing the goal. & 1 & 2 & 3 & 4 & 5 \\
\hline 6 & I have other goals that I am striving for as deeply as the one described. & 1 & 2 & 3 & 4 & 5 \\
\hline 7 & I put a lot of energy into achieving this goal. & 1 & 2 & 3 & 4 & 5 \\
\hline 8 & $\begin{array}{l}\text { When I don't do something aimed at achieving this goal, I feel like I am wasting } \\
\text { my time. }\end{array}$ & 1 & 2 & 3 & 4 & 5 \\
\hline 9 & I don't get bored spending long periods of time working towards this goal. & 1 & 2 & 3 & 4 & 5 \\
\hline 10 & I am sure that I will achieve my goal in the expected time frame. & 1 & 2 & 3 & 4 & 5 \\
\hline 11 & I have other goals that are just as satisfying as the one described. & 1 & 2 & 3 & 4 & 5 \\
\hline 12 & Other issues distract me easily when I am working to accomplish my goal. & 1 & 2 & 3 & 4 & 5 \\
\hline 13 & This goal is worth a lot of personal effort. & 1 & 2 & 3 & 4 & 5 \\
\hline 14 & I am worried that I won't fully achieve this goal. & 1 & 2 & 3 & 4 & 5 \\
\hline 15 & This goal strongly motivates me to take action. & 1 & 2 & 3 & 4 & 5 \\
\hline 16 & $\begin{array}{l}\text { Obstacles and problems I encounter on the way hinder my efforts aimed at } \\
\text { achieving the goal. }\end{array}$ & 1 & 2 & 3 & 4 & 5 \\
\hline 17 & If it wasn't for this goal, my life would be meaningless and disorganized. & 1 & 2 & 3 & 4 & 5 \\
\hline 18 & I get up early in the morning if I hav & 1 & 2 & 3 & 4 & 5 \\
\hline
\end{tabular}

Please make sure that you have answered all the questions! Thank you! 